\title{
Antidepressant-Like Activity of Methanolic Extract of the Seeds of Trachysperum ammi in Swiss Albino Mice
}

\author{
Md. Rashidur Rahman ${ }^{*}$, Mohammad Ali' ${ }^{1}$, Mostakim Sharif ${ }^{1}$, Sadiur Rahman Sajon', \\ Md. Abdul Mannan'2, Md. Shahed-Al-Mahmud ${ }^{3}$ \\ ${ }^{1}$ Department of Pharmacy, Jessore University of Science and Technology, Jessore, Bangladesh \\ ${ }^{2}$ Department of Pharmacy, Stamford University Bangladesh, Dhaka, Bangladesh \\ ${ }^{3}$ Department of Microbiology and Immunology, School of Medicine, Tzu Chi University, Hualian, Taiwan \\ Email: ^mr.rahman@just.edu.bd, md.ali_phrm@yahoo.com, mostakim20@gmail.com, sadiur.sajan@yahoo.com, \\ manna.034@gmail.com, shahed.shuvo16@gmail.com
}

How to cite this paper: Rahman, M.R., Ali, M., Sharif, M., Sajon, S.R., Mannan, M.A. and Shahed-Al-Mahmud, M. (2018) Antidepressant-Like Activity of Methanolic Extract of the Seeds of Trachysperum ammi in Swiss Albino Mice. Pharmacology \& Pharmacy, 9, 503-514.

https://doi.org/10.4236/pp.2018.912039

Received: November 6, 2018

Accepted: December 7, 2018

Published: December 10, 2018

Copyright () 2018 by authors and Scientific Research Publishing Inc. This work is licensed under the Creative Commons Attribution International License (CC BY 4.0).

http://creativecommons.org/licenses/by/4.0/

\begin{abstract}
Trachysperum ammi has been traditionally used for the treatment of neurological disorders such as depression and anxiety. To date, T. ammi has reported for its chemical constituents in different diseases condition. The traditional evidence convinced us to perform the antidepressant-like activity of methanolic extract of Trachysperum ammi (META). The antidepressant activity of META assessed by using forced swimming test (FST), tail suspension test (TST), and locomotor activity test. The seed parts of META at doses level of 50, 100 and $200 \mathrm{mg} / \mathrm{kg}$ body weight administered orally to examine the CNS stimulants activity test in mice behavioral models. Here, we reported that META significantly reduced immobility time in the FST after repeated administration of 50,100 and $200 \mathrm{mg} / \mathrm{kg}$ to mice for 14 days. The intensity of immobility significantly reduced at all of the doses $(p<0.05)$ whereas, we were found the strongest effect observed at $200 \mathrm{mg} / \mathrm{kg}$. The antidepressant-like effect of META caused the reduction $(\mathrm{p}<0.05)$ in the immobility in TST of mice when orally administered with 50, 100 and 200 $\mathrm{mg} / \mathrm{kg}$ for 14 days, respectively. Additionally, we were executed locomotor activity test to check the motor stimulating activity. META has employed at a dosage of 50, 100 and $200 \mathrm{mg} / \mathrm{kg}$ for 14 days, the results have found that 50 $\mathrm{mg} / \mathrm{kg}$ produced the locomotion effects as similar to the control group. Interestingly, the locomotion, rearing, and defecation significantly $(\mathrm{p}<0.05)$ increased at the dosage of 100 and $200 \mathrm{mg} / \mathrm{kg}$ of META. Our present findings suggest that the seed parts of Trachysperum ammi may possess antidepressant-like activity which may use as a supportive treatment to management of neurological disorders.
\end{abstract}




\section{Keywords}

Trachysperum ammi, Antidepressant, CNS Stimulants, Forced Swimming Test, Tail Suspension Test, Traditional Medicine

\section{Introduction}

Mental depression is a chronic mental disorder that distresses a person's mood, thoughts, physical health, and behavior. Combinations of biological and emotional components associated with depression. Retardation of thought, action, and appetite are biological symptoms \& emotional indicators include mystery, apathy and pessimism, low self-esteem consisting of feeling of guilt, inadequacy, and ugliness, indecisiveness, and loss of motivation [1]. World Health Report showed evidence that about 450 million people all over the world suffer from mental or behavioral syndrome [2]. It indicates about $12.3 \%$ of the worldwide burden of disease, and it may rise at $15 \%$ percent rate in 2020 [3]. Patients with major depressive disorder have symptoms that reflect changes in brain, monoamine neurotransmitters, specifically norepinephrine, serotonin, dopamine [4]. It anticipated that in 2020, after cardiovascular disease, depression may place at the second greatest increase rate of morbidity as a socioeconomic burden [5]. The number of drugs is available for treatment against depression, however, those drugs possess some serious side effects such as dry mouth, fatigue, gastrointestinal and respiratory problems, anxiety, agitation, drowsiness as well as cardiac arrhythmias [6]. Medicinal plants create an opportunity for alternative treatment for depression [7]. Drugs of natural origin are considered as safer and less complicated than synthetic drugs [8]. The aim of this study was to find out a new antidepressant drug from the natural origin.

Trachyspermum ammi is grown in the natural of Egypt and cultivated in Iraq, Iran, Afghanistan, Pakistan, and India. T. ammi L. belongs to family Apiaceae which is a highly valued medicinally important seed spice. The seed contains $2 \%-4.4 \%$ brown colored oil known as ajwain oil. The main component of this oil is thymol. The oil exhibits fungicidal [9], antimicrobial [10], and anti-inflammatory effects on humans. It plays an important role as remedial agent for flatulence, atonic dyspepsia, and diarrhea [11]. It also cures abdominal tumors, abdominal pains, and piles. T. ammi has been shown to possess hypolipidemic [12], digestive stimulant [13], antihypertensive, hepatoprotective, antispasmodic, bronchodilator [14], anti-lithiasis, diuretic [15], abortifacient [16], galactogogic [17], antiplatelet-aggregator, antitussive [18], anti-filarial [19], gastroprotective [20], nematicidal [21], anthelmintic [22], detoxification of aflatoxins [23], and ameliorative effects [24]. Thymol also used in toothpaste and perfumery [9]. Seeds of $T$. ammi are used traditionally in Lebanon as anti-rheumatic. Fixed oil from the seed contains resin acids, palmitic acid, petroselenic acid, oleic acid and linoleic acid [25]. 


\section{Materials and Methods}

\subsection{Plant Material Collection and Extraction}

The seed of Trachysperum ammi was collected from the local market of Jessore, Bangladesh. A herbarium sheet was prepared of that sample and sent for identification and authentication which was done by a Senior Scientific Officer at Bangladesh National Herbarium, Dhaka, Bangladesh. About $500 \mathrm{~g}$ of seeds powdered by using mortar-pestle and was dissolved in $750 \mathrm{~mL}$ of methanol. The powdered material was dissolved in methanol for $72 \mathrm{~h}$ in a beaker and mixture was stirred every $18 \mathrm{~h}$ using a sterile glass rod. Room temperature also carefully maintained at $25^{\circ} \mathrm{C} \pm 2^{\circ} \mathrm{C}$. The desire filtrate obtained after 3 times repetition by using the Whatman No. 1 filter paper and sterilized cotton filter. Filtrated solvent evaporates by the rotary evaporator; the percentage of yield of extract was $4.80 \%$.

\subsection{Experimental Animals}

Swiss Albino mice of both sex (20 - $25 \mathrm{~g}$ ) collected from the Animal Husbandry of Jahangirnagar University, Dhaka, Bangladesh. Animals were maintained under standard environmental conditions (temperature: $25^{\circ} \mathrm{C} \pm 2^{\circ} \mathrm{C}$, relative humidity: $55 \%-65 \%$ and $12 \mathrm{~h}$ light/dark cycle). During acclimatization period, food pellets provided to the mice with fresh water and libitum. The animals allowed acclimatizing to the laboratory condition for 14 days before experimental treatment. All the experimental animals treated following the Ethical Principles and Guidelines for Scientific Experiments on Animals (1995) formulated by the Swiss Academy of Medical Sciences and the Swiss Academy of Sciences. All the experimental animals were treated following the Ethical Principles and Guidelines for Scientific Experiments on Animals formulated by Ethical Review Committee, Faculty of Biological Sciences \& Technology, Jessore University of Science \& Technology (Ref: ERC/FBS/JUST/2017-02).

\subsection{Drugs and Treatments}

Imipramine hydrochloride (Sandoz, Novartis Bangladesh Ltd) used as the reference drug or positive control in antidepressant-like activity tests. All animals housed in a controlled room (temperature, $25^{\circ} \mathrm{C} \pm 1^{\circ} \mathrm{C}$; humidity, $45 \%$ - 50\%; light-dark cycle, $12 \mathrm{~h}$ each). Mice were divided randomly into control, positive control, and three experimental groups. Each group contained 5 mice and treated Deionized water $0.1 \mathrm{ml} / \mathrm{mice}$, Imipramine $\mathrm{HCl}$ (30 $\mathrm{mg} / \mathrm{kg}$ ), META (50 mg/kg), META (100 mg/kg), and META (200 mg/kg) respectively. Test solutions were administered orally using oral gavage once daily between 1-3 p.m. over a period of 14 days. All the experiments of these investigations were carried out at the Pharmacology Laboratory of the Department of Pharmacy, Jessore University of Science \& Technology, Bangladesh. 


\subsection{Experimental Methods}

\subsubsection{Forced Swimming Test (FST)}

FST performed according to the method which described by Porsolt et al., (1977) with some modifications [26] [27]. Animals exposed to a situation of forced swimming that based on behavioral despair, in which their movements reduced after a period of vigorous activity (struggling). However, the movements of swimming required to keep their heads above the water. Experimental mice placed in an acrylic cylinder $(45 \mathrm{~cm}$ height $=20 \mathrm{~cm}$ diameter) filled with water at $25^{\circ} \mathrm{C} \pm 1{ }^{\circ} \mathrm{C}$ to a depth of $17 \mathrm{~cm}$. According to above-mentioned apparatus, a trial session carried out (14-day treatment) which allowed the mice to swim for 15 minutes. Mouse considered immobile if it remained floating in the water, except for small movements to keep its head above the water. The FST performed between 1-3 p.m. and recorded using a video camera. The tapes evaluated by observers not informed about the kind of treatment each animal had received [28].

\subsubsection{Tail Suspension Test (TST)}

This test was performed according to the method described by Steru et al., (1985) [29] with slight modifications. TST is simple, reliable, and widely accepted behavioral despair model as well as screening antidepressant effect. TST involves suspending the tail of the mice upside down which shows the state of agitation and immobility as well this reflects a state of depression. TST apparatus contains two stands, each with a clamp located $22 \mathrm{~cm}$ from the floor, were placed at intervals of $23 \mathrm{~cm}$. Each mouse was hung $5 \mathrm{~cm}$ from the end of its tail on a stand and recorded with a video camera for $6 \mathrm{~min}$. The TST performed between 1-3 p.m. Immobility time was evaluated by observers.

\subsubsection{Measurement of Locomotors Activity Test (MLAT)}

The locomotor activity test performed according to the method of Carlini et al., (1986) [30] with some modifications. A mouse placed in an open field apparatus composed of an arena $40 \mathrm{~cm}$ in diameter divided into 64 approximately equal areas. During open field observations, each mouse individually placed in the center of the arena $15 \mathrm{~h}$ after the last treatment. Following behavioral parameters observed: locomotion (number of line crossings), rearing frequencies (number of times seen standing on hind legs), and number of defecations within $5 \mathrm{~min}$. Open field observations performed between 8-10 a.m.

\subsection{Statistical Analysis}

Statistical analysis of the experimental data performed using SPSS 23.0 version software. The statistical analysis was done by one-way analysis of variance (ANOVA) followed by Dunnett's post hoc test. The results presented as mean value \pm SEM $(n=5)$. The difference between the group was considered significant at a level of $\mathrm{p}^{*}<0.05$. The statistically significant results marked with a star $\left.{ }^{\star}\right)$ sign in the table as well as in the graph. 


\section{Results}

\subsection{Forced Swimming Test (FST)}

The META at doses level of 50, 100 and $200 \mathrm{mg} / \mathrm{kg}$ body weight on forced swimming test in mice observed (Table 1 ). The extracts of $T$. ammi significantly reduced the immobility time in FST. Interestingly, T. ammi reduced the immobility time notable at $200 \mathrm{mg} / \mathrm{kg}$ when compared with the control group (Figure 1). Imipramine $\mathrm{HCl}$ also showed the same antidepressant manner.

\subsection{Tail Suspension Test (TST)}

The META at doses level of 50, 100 and $200 \mathrm{mg} / \mathrm{kg}$ body weight on tail suspension in mice showed the positive result (Table 2). The immobility time in the TST using mice markedly reduced after acute 14 days treatment with Imipramine $\mathrm{HCl}(30 \mathrm{mg} / \mathrm{kg})$. Administration of extracts of T. ammi at dosages of 50, 100 , and $200 \mathrm{mg} / \mathrm{kg}$ significantly reduced the immobility time (Figure 2).

\subsection{Measurement of Locomotor Activity Test (MLAT)}

The META at doses level of 50, 100 and $200 \mathrm{mg} / \mathrm{kg}$ body weight on the measurement of locomotor activity test in mice observed. The extracts of $T$. ammi $(50 \mathrm{mg} / \mathrm{kg}$ ) shown that the same locomotion effect of the control group (Table 3). However, $100 \mathrm{mg} / \mathrm{Kg}$ and $200 \mathrm{mg} / \mathrm{kg}$ doses of $T$. ammi shown the significant increase of locomotion, rearing, and defecation. All the test animals compared with positive control (Figures 3(a)-3(c)).

Table 1. Effect of META in forced swimming test on mice.

\begin{tabular}{ccc}
\hline Treatment & Doses & Immobility time \\
\hline Deionized water & $0.1 \mathrm{ml} / \mathrm{mice}$ & $106.20 \pm 17.890$ \\
Imipramine Hydrochloride & $30 \mathrm{mg} / \mathrm{kg}$ & $18.50 \pm 3.403^{*}$ \\
META & $50 \mathrm{mg} / \mathrm{kg}$ & $46.25 \pm 5.250^{*}$ \\
META & $100 \mathrm{mg} / \mathrm{kg}$ & $41.0 \pm 2.121^{*}$ \\
META & $200 \mathrm{mg} / \mathrm{kg}$ & $31.80 \pm 7.479^{*}$ \\
\hline
\end{tabular}

Values are presented as mean \pm SEM, where $\mathrm{n}=5$. Control $=$ Distilled water, $0.1 \mathrm{ml} / \mathrm{mice}$, Imipramine $\mathrm{HCl}$ $=30 \mathrm{mg} / \mathrm{kg}$, Group META $=50,100$ and $200 \mathrm{mg} / \mathrm{kg}$ body weight. ${ }^{*} \mathrm{p}<0.05$ compared with the control group (Dunnett's test).

Table 2. Effect of META in tail suspension test on mice.

\begin{tabular}{ccc}
\hline Treatment & Doses & Immobility time \\
\hline Deionized water & $0.1 \mathrm{ml} / \mathrm{mice}$ & $105.87 \pm 1.612$ \\
Imipramine Hydrochloride & $30 \mathrm{mg} / \mathrm{kg}$ & $17.25 \pm 2.750^{\star}$ \\
META & $50 \mathrm{mg} / \mathrm{kg}$ & $51.25 \pm 9.690^{\star}$ \\
META & $100 \mathrm{mg} / \mathrm{kg}$ & $34.25 \pm 5.677^{\star}$ \\
META & $200 \mathrm{mg} / \mathrm{kg}$ & $28.4 \pm 2.293^{\star}$ \\
\hline
\end{tabular}

Values are presented as mean $\pm \mathrm{SEM}$, where $\mathrm{n}=5$. Control $=$ Distilled water, $0.1 \mathrm{ml} / \mathrm{mice}$, Imipramine $\mathrm{HCl}$ $=30 \mathrm{mg} / \mathrm{kg}$, Group META $=50,100$ and $200 \mathrm{mg} / \mathrm{kg}$ body weight. ${ }^{*} \mathrm{p}<0.05$ compared with the control group (Dunnett's test). 
Table 3. Effect of META in locomotor activity test on mice.

\begin{tabular}{ccccc}
\hline Treatment & Doses & Locomotion & Rearing & Defecation \\
\hline Deionized water & $0.1 \mathrm{ml} / \mathrm{mice}$ & $94.0 \pm 3.768$ & $16.2 \pm 4.841$ & $0.80 \pm 0.583$ \\
Imipramine Hydrochloride & $30 \mathrm{mg} / \mathrm{kg}$ & $206.25 \pm 10.0^{*}$ & $37.75 \pm 1.75^{\star}$ & $3.25 \pm 0.25^{*}$ \\
META & $50 \mathrm{mg} / \mathrm{kg}$ & $118.2 \pm 9.903$ & $21 \pm 1.472$ & $2.00 \pm 0.408$ \\
META & $100 \mathrm{mg} / \mathrm{kg}$ & $159.5 \pm 7.963^{*}$ & $26.5 \pm 0.866^{*}$ & $2.25 \pm 0.25^{*}$ \\
META & $200 \mathrm{mg} / \mathrm{kg}$ & $177.2 \pm 28.34^{*}$ & $34.2 \pm 1.655^{\star}$ & $3.00 \pm 0.316^{*}$ \\
\hline
\end{tabular}

Values are presented as mean \pm SEM, where $\mathrm{n}=5$. Control = Distilled water, $0.1 \mathrm{ml} / \mathrm{mice}$, Imipramine $\mathrm{HCl}$ $=30 \mathrm{mg} / \mathrm{kg}$, Group META $=50,100$ and $200 \mathrm{mg} / \mathrm{kg}$ body weight. ${ }^{*} \mathrm{p}<0.05$ compared with the control group (Dunnett's test).

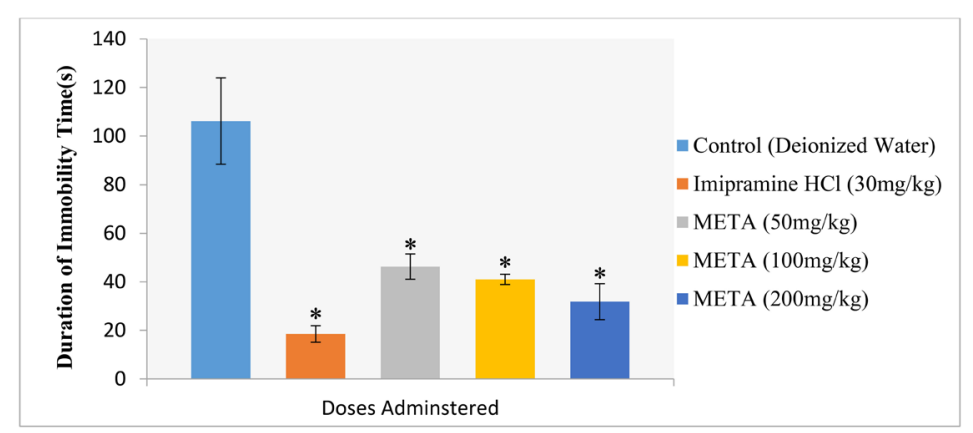

Figure 1. Graphical representation of effect of META in forced swimming test on immobility time in mice. ${ }^{*} \mathrm{p}<0.05$ compared with the control group (Dunnett's test).

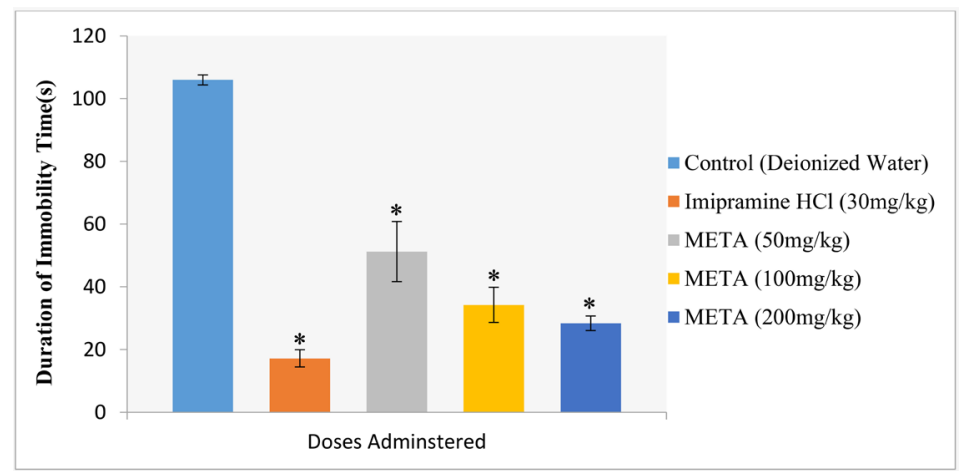

Figure 2. Graphical representation of effect of META on tail suspension test on immobility time in mice. ${ }^{*} \mathrm{p}<0.05$ compared with the control group (Dunnett's test).

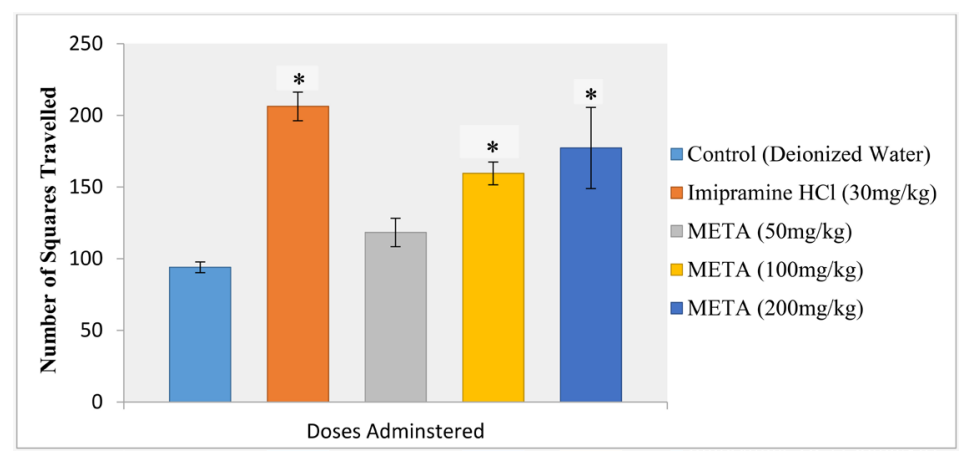

(a) 


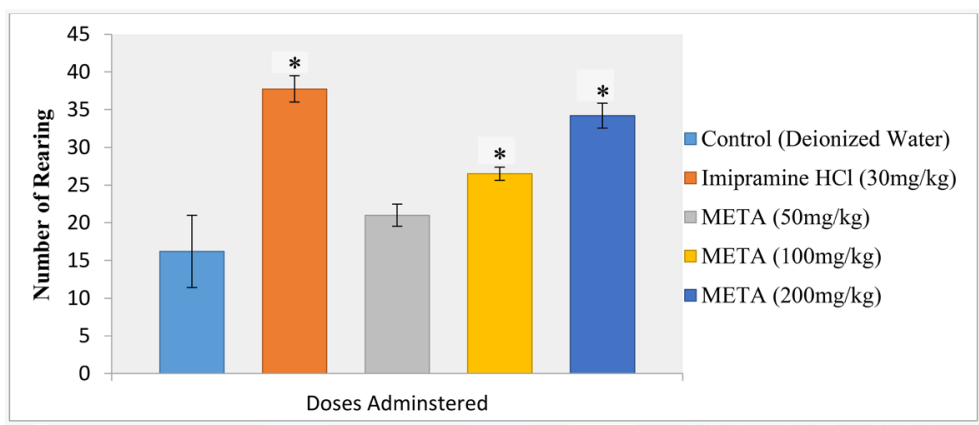

(b)

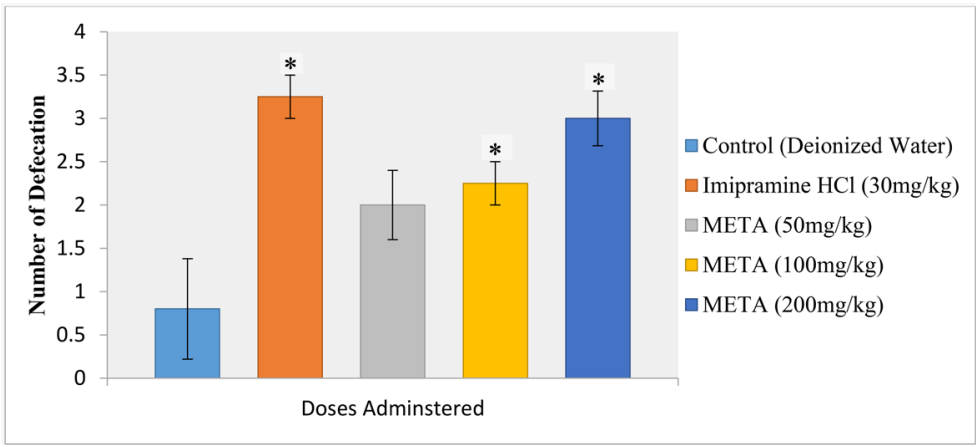

(c)

Figure 3. (a) Graphical representation of effect of META on measurement of locomotor activity test of locomotion in mice. ${ }^{*} \mathrm{p}<0.05$ compared with the control group (Dunnett's test). (b) Graphical representation of effect of META on measurement of locomotor activity test of rearing in mice. ${ }^{*} \mathrm{p}<0.05$ compared with the control group (Dunnett's test). (c) Graphical representation of effect of META on measurement of locomotor activity test of defecation on mice. ${ }^{*} \mathrm{p}<0.05$ compared with the control group (Dunnett's test).

\section{Discussion}

Many of the plants used as crude extracts and purified natural products [31] [32] which have potential medicinal properties [33]. The aimed of our present study to evaluate the antidepressant-like effects of methanolic extract of the seeds of T. ammi using behavioral animal models. Our present study indicates that the antidepressant-like effect of META found to compare with the standard drug Imipramine hydrochloride $(30 \mathrm{mg} / \mathrm{kg}$ ). Imipramine hydrochloride acts by inhibiting norepinephrine reuptake and has used as a standard drug in majority studies. Rodents displayed immobility when unavoidable stress subjected such as forced swimming is thought to reflect a state of despair or lowered mood. This condition reflects depressive disorders in humans. Additionally, the antidepressant drugs treatment reduced the immobility time. Moreover, a significant correlation found between the clinical efficacy of antidepressant drugs and their potency in this model. In the present study, META significantly reduced immobility time in the FST after repeated administration of 50, 100 and $200 \mathrm{mg} / \mathrm{kg}$ to mice for $14 \mathrm{~d}$. The intensity of immobility reduction was statistically significant at all doses $\left(\mathrm{p}^{*}<0.05\right)$ but strongest at a dosage of $200 \mathrm{mg} / \mathrm{kg}$. 
META exhibited a reduction in the time of immobility at the dose of 50 and $100 \mathrm{mg} / \mathrm{kg}$. Interestingly, $200 \mathrm{mg} / \mathrm{kg}$ was produced the higher reduction of immobility compared with the control group. The efficacy of immobility decreased in the FST \& TST which may occur with psycho-stimulants, exert an indiscriminate motor stimulating activity [34]. The motor stimulating activity of META was performed with the open field test to exclude the confusion. The administration of META at a dosage of 50, 100 and $200 \mathrm{mg} / \mathrm{kg}$ for $14 \mathrm{~d}$ exerts statistically significant $\left(\mathrm{p}^{*}<0.05\right)$ at the doses of 100 and $200 \mathrm{mg} / \mathrm{kg}$ as well as also indicates that the reduction of immobility time after $14 \mathrm{~d}$ administration of META attributed to an inherent antidepressant effect. Thus, the effective dosage of META in the FST seems to be around $200 \mathrm{mg} / \mathrm{kg}$ body weight.

The beneficial effect of Imipramine hydrochloride in TST model seems to be due to increased availability of these neurotransmitters (NE) and serotonin $(5 \mathrm{HT})$ at the postsynaptic site following reuptake inhibition [35]. Some researchers already have shown the adaptogenic effect of the plant extract via normalization of the various stress parameters and monoaminergic levels [36]. Those studies may provide a hint about extract which involved in possible antidepressant-like effect through the restoration of normal monoaminergic NE [37]. The action of the triterpenoid and saponins resulted in the enhancement of the nerve impulse transmission. Neurochemical assays suggested that treatment by triterpenoid and saponins improved brain antioxidant activity to varying degrees after the behavioral despair test [38]. The pattern of CNS effects observed through this experiment suggests us the involvement of norepinephrine NE system on its antidepressant-like effect.

\section{Conclusion}

The findings obtained from forced swimming test (FST), tail suspension test (TST), and measurement of locomotor activity test (MLAT) clearly indicate that the methanolic extract of the seeds of Trachysperum ammi possesses a significant antidepressant-like activity. The outcome also indicates that the antidepressant-like activity observed without the involvement of non-specific motor stimulation. However, different research approach must be needed to elucidate the mechanism of action of Trachysperum ammi. The experimental findings suggest the antidepressant-like effects that may involve in norepinephrine neurotransmitters system.

\section{Ethical Approval}

All procedures performed in this study involving animals were approved in accordance with the ethical standards of the Ethical Review Committee, Faculty of Biological Sciences and Technology, Jessore University of Science and Technology, Jessore, Bangladesh (Ref: ERC/FBS/JUST/2017-02).

\section{Consent for Publication}

Not applicable. 


\section{Availability of Data and Material}

Not applicable.

\section{Funding}

This research did not receive any specific grant from funding agencies in the public, commercial, or not-for-profit sectors.

\section{Authors' Contributions}

Md. Rashidur Rahman designed, and supervised the experimental work. Mohammad Ali, Mostakim Sharif, and Sadiur Rahman Sajon coordinated forced swimming test, tail suspension test, and locomotor activity test and interpreted the results. Md. Abdul Mannan has done statistical analysis and drawn the graphs. Md. Shahed-Al-Mahmud drafted the manuscript. All authors read and approved the manuscript.

\section{Acknowledgements}

The authors are grateful to the chairman of the department of Pharmacy, Jessore University of Science and Technology for permitting us to use the facilities of Pharmacognosy and Pharmacology Laboratory.

\section{Authors' Information (Optional)}

1 - 4 Department of Pharmacy, Jessore University of Science and Technology, Jessore, Bangladesh.

5 Department of Pharmacy, Stamford University Bangladesh, Dhaka, Bangladesh.

6 Department of Microbiology and Immunology, School of Medicine, Tzu Chi University, Hualian, Taiwan.

\section{Conflicts of Interest}

The authors declare no conflicts of interest regarding the publication of this paper.

\section{References}

[1] Keya, S.N., Shahed-Al-Mahmud, M. and Rahman, M.R. (2018) Antidepressant-Like Effects of Methanolic Extract of Xanthium strumarium (Asteraceae) in Mice. Current Trends in Biotechnology and Pharmacy, 12, 33-37.

[2] World Health Organization (2001) The World Health Report 2001: Mental Health: New Understanding, New Hope.

[3] Weyand, C.M. and Goronzy, J.J. (2018) Vasculitides. Primer on the Rheumatic Diseases, 1, 398-450.

[4] Gold, P.W., Goodwin, F.K. and Chrousos, G.P. (1988) Clinical and Biochemical Manifestations of Depression. New England Journal of Medicine, 319, 413-420. https://doi.org/10.1056/NEJM198808183190706

[5] Hoge, C.W., Auchterlonie, J.L. and Milliken, C.S. (2006) Mental Health Problems, 
Use of Mental Health Services, and Attrition from Military Service after Returning from Deployment to Iraq or Afghanistan. JAMA, 295, 1023-1032. https://doi.org/10.1001/jama.295.9.1023

[6] Zhang, Z.-J. (2004) Therapeutic Effects of Herbal Extracts and Constituents in Animal Models of Psychiatric Disorders. Life Sciences, 75, 1659-1699.

https://doi.org/10.1016/j.lfs.2004.04.014

[7] Shahed-Al-Mahmud, M. and Lina, S.M.M. (2018) Evaluation of Sedative and Anxiolytic Activities of Methanol Extract of Leaves of Persicaria hydropiper in Mice. Clinical Phytoscience, 3, 20.

[8] Saha, A.K., Rahman, M.R., Shahriar, M., Saha, S.K., Al Azad, N. and Das, S. (2013) Screening of Six Ayurvedic Medicinal Plant Extracts for Antioxidant and Cytotoxic Activity. Journal of Pharmacognosy and Phytochemistry, 2, 181-188.

[9] Srivastava, K. (1988) Extract of a Spice-Omum (Trachyspermum ammi)-Shows Antiaggregatory Effects and Alters Arachidonic Acid Metabolism in Human Platelets. Prostaglandins, Leukotrienes and Essential Fatty Acids, 33, 1-6. https://doi.org/10.1016/0952-3278(88)90115-9

[10] Rizk, A.F.M. (1987) The Chemical Constituents and Economic Plants of the Euphorbiaceae. Botanical Journal of the Linnean Society, 94, 293-326. https://doi.org/10.1111/j.1095-8339.1987.tb01052.x

[11] Warrier, P.K. and Nambiar, V. (1993) Indian Medicinal Plants: A Compendium of 500 Species. Vol. 5, Orient Blackswan.

[12] Kumari, K. and Prameela, M. (1992) Effect of Incorporating Carum Copticum Seeds in a High Fat Diet for Albino Rats. Medical Science Research.

[13] Vasudevan, K., Vembar, S., Veeraraghavan, K. and Haranath, P. (2000) Influence of Intragastric Perfusion of Aqueous Spice Extracts on Acid Secretion in Anesthetized Albino Rats. Indian Journal of Gastroenterology: Official Journal of the Indian Society of Gastroenterology, 19, 53-56.

[14] Gilani, A., Jabeen, Q., Ghayur, M., Janbaz, K. and Akhtar, M. (2005) Studies on the Antihypertensive, Antispasmodic, Bronchodilator and Hepatoprotective Activities of the Carum copticum Seed Extract. Journal of Ethnopharmacology, 98, 127-135. https://doi.org/10.1016/j.jep.2005.01.017

[15] Ahsan, S., Shah, A., Tanira, M., Ahmad, M., Tariq, M. and Ageel, A. (1990) Studies on Some Herbal Drugs Used against Kidney Stones in Saudi Folk Medicine. Fitoterapia, 61, 435-438.

[16] Nath, D., Sethi, N., Srivastava, S., Jain, A. and Srivastava, R. (1997) Survey on Indigenous Medicinal Plants Used for Abortion in Some Districts of Uttar Pradesh. Fitoterapia, 68, 223-225.

[17] Kaur, H. (1998) Estrogenic Activity of Some Herbal Galactogogue Constituents. Indian Journal of Animal Nutrition, 15, 232-234.

[18] Boskabady, M., Jandaghi, P., Kiani, S. and Hasanzadeh, L. (2005) Antitussive Effect of Carum copticum in Guinea Pigs. Journal of Ethnopharmacology, 97, 79-82. https://doi.org/10.1016/j.jep.2004.10.016

[19] Mathew, N., Misra-Bhattacharya, S., Perumal, V. and Muthuswamy, K. (2008) Antifilarial Lead Molecules Isolated from Trachyspermum ammi. Molecules, 13, 2156-2168. https://doi.org/10.3390/molecules13092156

[20] Ramaswamy, S., Sengottuvelu, S., Sherief, S.H., Jaikumar, S., Saravanan, R., Prasadkumar, C. and Sivakumar, T. (2010) Gastroprotective Activity of Ethanolic Extract of Trachyspermum ammi Fruit. International Journal of Pharma and Bio Sciences, 
$1,1-15$.

[21] Pelczar, M., Chan, E. and Krieg, N. (1988) Control of Microorganisms, the Control of Microorganisms by Physical Agents. In: Microbiology, McGraw-Hill International, New York, 469-509.

[22] Priestley, C.M., Williamson, E.M., Wafford, K.A. and Sattelle, D.B. (2003) Thymol, a Constituent of Thyme Essential Oil, Is a Positive Allosteric Modulator of Human GABAA Receptors and a Homo-Oligomeric GABA Receptor from Drosophila melanogaster. British Journal of Pharmacology, 140, 1363-1372. https://doi.org/10.1038/sj.bjp.0705542

[23] Velazhahan, R., Vijayanandraj, S., Vijayasamundeeswari, A., Paranidharan, V., Samiyappan, R., Iwamoto, T., Friebe, B. and Muthukrishnan, S. (2010) Detoxification of Aflatoxins by Seed Extracts of the Medicinal Plant, Trachyspermum ammi (L.) Sprague ex Turrill-Structural Analysis and Biological Toxicity of Degradation Product of Aflatoxin G1. Food Control, 21, 719-725.

https://doi.org/10.1016/j.foodcont.2009.10.014

[24] Anilakumar, K., Saritha, V., Khanum, F. and Bawa, A. (2009) Ameliorative Effect of Ajwain Extract on Hexachlorocyclohexane-Induced Lipid Peroxidation in Rat Liver.

Food and Chemical Toxicology, 47, 279-282.

https://doi.org/10.1016/j.fct.2008.09.061

[25] Nelly, A., Annick, D.-D. and Frederic, D. (2008) Plants Used as Remedies Antirheumatic and Antineuralgic in the Traditional Medicine of Lebanon. Journal of Ethnopharmacology, 120, 315-334. https://doi.org/10.1016/j.jep.2008.08.024

[26] Porsolt, R., Le Pichon, M. and Jalfre, M. (1977) Depression: A New Animal Model Sensitive to Antidepressant Treatments. Nature, 266, 730.

https://doi.org/10.1038/266730a0

[27] Porsolt, R., Bertin, A. and Jalfre, M. (1977) Behavioral Despair in Mice: A Primary Screening Test for Antidepressants. Archives Internationales de Pharmacodynamie et de Therapie, 229, 327-336.

[28] Sakakibara, H., Ishida, K., Grundmann, O., Nakajima, J.-I., Seo, S., Butterweck, V., Minami, Y., Saito, S., Kawai, Y. and Nakaya, Y. (2006) Antidepressant Effect of Extracts from Ginkgo biloba Leaves in Behavioral Models. Biological and Pharmaceutical Bulletin, 29, 1767-1770. https://doi.org/10.1248/bpb.29.1767

[29] Steru, L., Chermat, R., Thierry, B. and Simon, P. (1985) The Tail Suspension Test: A New Method for Screening Antidepressants in Mice. Psychopharmacology, 85, 367-370. https://doi.org/10.1007/BF00428203

[30] Carlini, E.A., Contar, J.D.D., Silva-Filho, A.R., Da Silveira-Filho, N.G., Frochtengarten, M.L. and Bueno, O.F. (1986) Pharmacology of Lemongrass (Cymbopogon citratus Stapf). I. Effects of Teas Prepared from the Leaves on Laboratory Animals. Journal of Ethnopharmacology, 17, 37-64. https://doi.org/10.1016/0378-8741(86)90072-3

[31] Shahed-Al-Mahmud, M., Jahan, T. and Islam, M.T. (2018) Antidiarrheal Activities of Hydroalcoholic Extract of Sida cordifolia Roots in Wister Albino Rats. Oriental Pharmacy and Experimental Medicine, 18, 51-58. https://doi.org/10.1007/s13596-017-0295-5

[32] Shahed-Al-Mahmud, M., Shawon, M.J.A., Islam, T., Rahman, M.M. and Rahman, M.R. (2018) In Vivo Anti-Diarrheal Activity of Methanolic Extract of Streblus asper Leaves Stimulating the $\mathrm{Na}+\mathrm{K}+$-ATPase in Swiss Albino Rats. Indian Journal of Clinical Biochemistry, 1-8.

[33] Sarwar, S., Rahman, M.R., Nahar, K. and Rahman, M.A. (2014) Analgesic and Neu- 
ropharmacological Activities of Methanolic Leaf Extract of Clitoria ternatea Linn. Journal of Pharmacognosy and Phytochemistry, 2, 110-114.

[34] Mannan, A., Abir, A.B. and Rahman, R. (2015) Antidepressant-Like Effects of Methanolic Extract of Bacopa monniera in Mice. BMC Complementary and Alternative Medicine, 15, 337. https://doi.org/10.1186/s12906-015-0866-2

[35] Vergura, R., Balboni, G., Spagnolo, B., Gavioli, E., Lambert, D.G., McDonald, J., Trapella, C., Lazarus, L.H., Regoli, D. and Guerrini, R. (2008) Anxiolytic- and Antidepressant-Like Activities of H-Dmt-Tic-NH-CH (CH2-COOH)-Bid (UFP-512), a Novel Selective Delta Opioid Receptor Agonist. Peptides, 29, 93-103. https://doi.org/10.1016/j.peptides.2007.10.012

[36] Ismail, H., Amanat, M.A., Iqbal, A. and Mirza, B. (2018) Medicinal Plants: A Complementary and Alternative Antidepressant Therapy. Current Pharmaceutical Design, 24, 2609-2624. https://doi.org/10.2174/1381612824666180727123950

[37] Abouhosseini Tabari, M., Hajizadeh Moghaddam, A., Maggi, F. and Benelli, G. (2018) Anxiolytic and Antidepressant Activities of Pelargonium roseum Essential Oil on Swiss Albino Mice: Possible Involvement of Serotonergic Transmission. Phytotherapy Research, 32, 1014-1022. https://doi.org/10.1002/ptr.6038

[38] Prasad, R., Kamal, S., Sharma, P.K., Oelmüller, R. and Varma, A. (2013) Root Endophyte Piriformospora indica DSM 11827 Alters Plant Morphology, Enhances Biomass and Antioxidant Activity of Medicinal Plant Bacopa monniera. Journal of Basic Microbiology, 53, 1016-1024. https://doi.org/10.1002/jobm.201200367

\section{Abbreviations}

META: Methanolic Extract of the seeds of Trachysperum ammi

FST: Forced Swimming Test

TST: Tail Suspension Test

NE: Neurotransmitters

Min: minutes 